\title{
Nitrogen response of natural phytoplankton communities: a new indicator based on photosynthetic efficiency $F_{\mathrm{v}} / F_{\mathrm{m}}$
}

\author{
Emily Ann Saeck ${ }^{1, *}$, Katherine Rosemary O'Brien ${ }^{2}$, Michele Astrid Burford ${ }^{1}$
}

${ }^{1}$ Australian Rivers Institute, Griffith University, 170 Kessels Road, Nathan, Queensland 4111, Australia

${ }^{2}$ School of Chemical Engineering, The University of Queensland, Brisbane, Queensland 4072, Australia

\begin{abstract}
The availability of the primary limiting nutrient plays a major role in driving the productivity, biomass and community composition of coastal phytoplankton, but there is an ongoing challenge to define the relationship between nutrient enrichment and phytoplankton response. This study explored a new indicator $\left(\mathrm{N}_{95}\right)$ for quantifying nutrient response in natural phytoplankton communities. In this study, $\mathrm{N}_{95}$ specifically represented the required nitrogen addition (normalised to chlorophyll a) for the sampled phytoplankton population to reach $95 \%$ of nitrogenreplete photosynthetic efficiency. To calculate $\mathrm{N}_{95}$, an asymptotic model was applied to measures of phytoplankton photosynthetic efficiency $\left(F_{\mathrm{v}} / F_{\mathrm{m}}\right)$ taken after $24 \mathrm{~h}$ incubations under a range of nitrogen enrichment treatments. Applying the method in an Australian subtropical bay, Moreton Bay, nitrogen response was lowest nearshore and high, yet variable, offshore. This pattern reflected the ambient nutrient gradient of declining concentrations with distance offshore. A Moreton Bay-specific threshold in phytoplankton nutrient response was identified at the ambient dissolved inorganic nitrogen concentration of $2 \mu \mathrm{mol} \mathrm{l}^{-1}$, above which the response to nitrogen enrichment did not increase for $82 \%$ of samples. Advantages to measuring $\mathrm{N}_{95}$ were that incubations were simple to set up, incubation period was short, and $F_{\mathrm{v}} / F_{\mathrm{m}}$ measures were simple to make. This approach advances options for using $F_{\mathrm{v}} / F_{\mathrm{m}}$ measures to assess phytoplankton nutrient response and provides a new and sensitive biological indicator applicable to long-term water quality monitoring programs, relevant to parameterising ecological models and supporting decision making on nutrient management.
\end{abstract}

KEY WORDS: Microalgae · Microbial $\cdot$ Eutrophication · Bioassay $\cdot$ PHYTO-PAM $\cdot$ Fluorescence Maximum quantum yield of PSII

\section{INTRODUCTION}

The ability to measure the response of phytoplankton to nutrient enrichment is of considerable importance to understanding phytoplankton ecology in aquatic systems and to nutrient management practices. However, measuring nutrient stress in natural phytoplankton communities and predicting phytoplankton response to enrichment is challenging. The challenges arise in natural communities because phytoplankton rate processes are the product not only of external nutrient supply but also of internal cellular nutrient pools, the physiology of each of the species present in a community and ambient conditions (e.g. temperature and light) at the time of sampling (Syrett 1981, Hecky \& Kilham 1988, Riebesell \& Wolf-Gladrow 2002). It is further complicated by the difficulty in measuring true nutrient availability because nutrient pools are highly dynamic, with regeneration and uptake occurring at time scales shorter than can be measured. 
Nutrient limitation cannot be directly measured; however, a popular and powerful indicator of nutrient stress in phytoplankton is the fluorescence-based measure of photosynthetic efficiency: maximum quantum yield of PSII $\left(F_{\mathrm{v}} / F_{\mathrm{m}}\right)$ (Geider et al. 1993, Beardall et al. 2001, Lippemeier et al. 2001). Evidence from enrichment of natural populations in the field (Kolber et al. 1994, Behrenfeld et al. 1996) and laboratory bioassays (Wood \& Oliver 1995, Burford et al. 2011) indicates that $F_{\mathrm{v}} / F_{\mathrm{m}}$ is relatively higher when nutrient levels are higher, and this pattern is correlated with higher growth and primary productivity rates. The theoretical basis for this pattern is that when phytoplankton growth is stressed by an under-supply of nutrients, the photosynthetic apparatus, energy transduction, carbon fixation and nutrient uptake/assimilation processes of the cell are all compromised (Geider et al. 1993, Beardall et al. 2001). Measures of photosynthetic efficiency alone cannot be directly related to phytoplankton growth rates because photosynthetic energy produced by a cell is used for basic cellular metabolism, not just growth (Geider et al. 1993, Beardall et al. 2001, Lippemeier et al. 2001). However, an observed increase in photosynthetic efficiency following nutrient enrichment indicates that there is potential for increased nutrient uptake, carbon assimilation, cell division and growth.

This study explored a novel technique, using phytoplankton $F_{\mathrm{v}} / F_{\mathrm{m}}$ measures, to quantify phytoplankton nutrient response in natural communities and to indicate sensitivity to nutrient enrichment. Previous studies, such as Wood \& Oliver (1995), Burford et al. (2011) and Saeck et al. (2013a), have used $F_{\mathrm{v}} / F_{\mathrm{m}}$ measured following short $(24 \mathrm{~h})$ incubation enrichment bioassays to identify nutrient response, in terms of a categorical state (i.e. nutrient responsive or not nutrient responsive). The benefit of such bioassays for assessing natural phytoplankton is that the observed nutrient response more closely reflects the in situ ecological state of the natural mixed-species community compared to available alternative techniques, such as growth experiments (Beardall et al. 2001). However, to our knowledge, no previous study has used $F_{\mathrm{v}} / F_{\mathrm{m}}$ response to increasing concentrations of nutrient enrichment to quantify, not just the categorical state (i.e. nutrient responsive or not nutrient responsive), but the degree of nutrient response. Prior studies demonstrate that the behaviour of phytoplankton $F_{\mathrm{v}} / F_{\mathrm{m}}$ in response to nutrient perturbations is influenced by factors such as prior nutrient conditions (i.e. nutrient limited vs. nutrient starved) (Lippemeier et al. 2001, Parkhill et al. 2001, Young \&
Beardall 2003b); the phytoplankton species present in the sampled community (Geider et al. 1993, Lippemeier et al. 2001); the specific nutrient form that was limiting physiological processes (Kruskopf \& Flynn 2006); and when $F_{\mathrm{v}} / F_{\mathrm{m}}$ was measured relative to the time since enrichment (Lippemeier et al. 2001, Young \& Beardall 2003a,b). These factors that influence $F_{\mathrm{v}} / F_{\mathrm{m}}$ are extensively characterised in the literature and were used in this study to guide the design of a technique for quantifying an indicator of nutrient response in natural phytoplankton communities.

The value of quantifying nutrient response is that it provides a continuous response variable that can be assessed against environmental drivers and used to characterise the spatial and temporal variability of nutrient response across a system, to identify regions with greatest sensitivity to nutrient enrichment and to quantify ecologically significant relationships, such as thresholds for nutrient response. In this study, a newly developed technique was applied to a coastal system. The aim was to compare patterns in phytoplankton nutrient status with ambient nutrient concentrations and to identify relationships that can predict phytoplankton response to nutrient enrichment. The coastal system studied was Moreton Bay, in subtropical Australia, which has a distinct west to east nutrient gradient caused by river inflow. Previous studies have identified nitrogen as the primary limiting nutrient of phytoplankton growth and productivity in Moreton Bay (O'Donohue \& Dennison 1997, Glibert et al. 2006, Saeck et al. 2013b). This study demonstrates that improved knowledge of nutrient response characteristics can be used to predict nutrient conditions that have potential to cause shifts in the state of phytoplankton communities. Such information is valuable scientific input for developing nutrient management strategies and curbing degradation of the world's coastal zones due to eutrophication.

\section{MATERIALS AND METHODS}

\section{Study area}

Moreton Bay is a shallow subtropical system on the southeast coast of Queensland, Australia (27 $17^{\prime} \mathrm{S}$, $\left.153^{\circ} 15^{\prime} \mathrm{E}\right)$ (Fig. 1). Surface water temperatures throughout the year range between 16 and $29^{\circ} \mathrm{C}$. The drainage basin has an area of $19430 \mathrm{~km}^{2}$, with a mixture of urban and rural land use, and a human population of approximately 3.05 million (Skinner et al. 1998, Australian Bureau of Statistics 2012). A number 


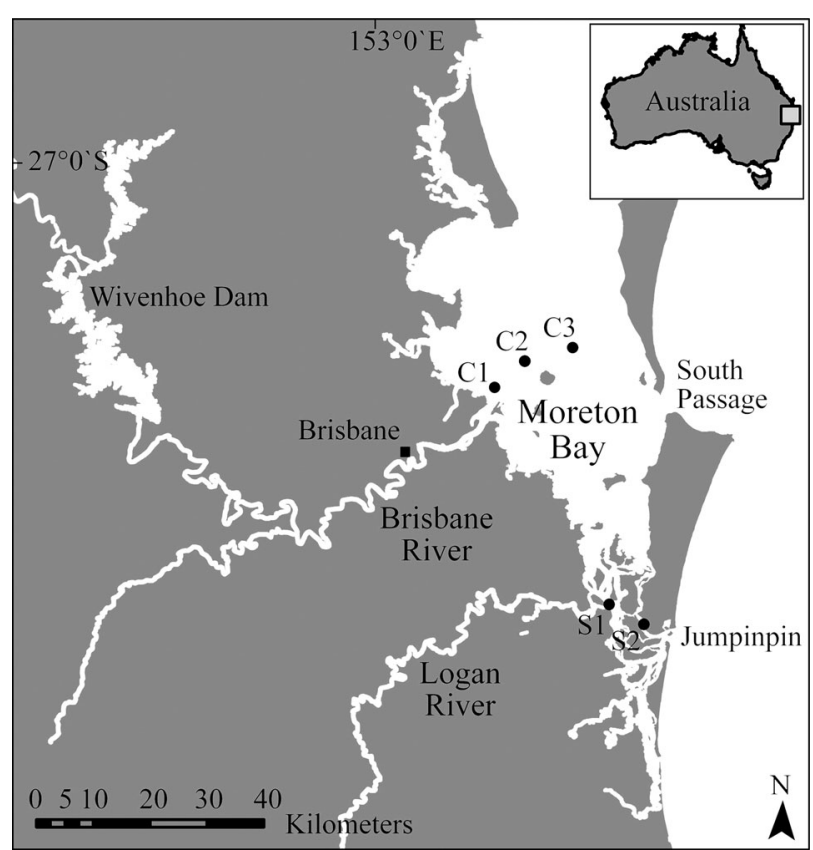

Fig. 1. The stations in central (C) and southern (S) Moreton Bay used in this study. Stations capture an east to west gradient of nutrients associated with the river plume from the Brisbane and Logan Rivers

of rivers discharge into the western side of the bay, including the Brisbane and Logan Rivers. Monsoonal rainfall during the wet season (September to April) causes pulsed river flows and contributes significant sediment and nutrient inputs to the bay (Eyre et al. 1998). During dryer months, the mouths of the rivers are poorly flushed due to prevailing onshore winds. As a result, the western side of the bay has higher nutrient and chlorophyll a (chl a) concentrations compared to the eastern areas (O'Donohue \& Dennison 1997). Compared to other river and estuarine systems around the world, Moreton Bay has low areal productivity $\left(<0.6 \mathrm{~g} \mathrm{C} \mathrm{m}^{-2} \mathrm{~d}^{-1}\right)$ due to light and nitrogen limitation during summer and growth-limiting temperatures during winter (O'Donohue \& Dennison 1997, Eyre \& McKee 1999, O'Donohue et al. 2000).

In terms of river discharges into central Moreton Bay, Brisbane River drains $62 \%$ of the total Moreton Bay catchment (Dennison \& Abal 1999). The nearshore zone of central Moreton Bay is shallow $(<3 \mathrm{~m})$ and has the longest residence time within Moreton Bay ( 60 d) (McEwan et al. 1998). Water depth increases with distance offshore, reaching a maximum at $\sim 10 \mathrm{~m}$. This area of the bay is open with no mangrove islands present. The other major river discharging into Moreton Bay is the Logan River, which discharges directly into the network of channels at the southern end of Moreton Bay. In contrast to cen- tral Moreton Bay, this delta system is a low-energy zone with extensive mudflats, mangrove and salt marsh habitats. This section of the bay has a long water residence time, reaching up to $48 \mathrm{~d}$ on the western side (Abal et al. 2002, McCauley \& Tomlinson 2006).

\section{Assessing water quality gradients}

Sampling for surface water quality data (chl $a$, dissolved inorganic nitrogen [DIN], soluble reactive phosphorus [SRP], salinity and temperature) was carried out monthly at the 5 Moreton Bay stations from January 2006 to December 2010 (Fig. 1). Samples were collected as part of a local government longterm water-quality monitoring program for Moreton Bay (Stns C1, C2, C3, S1 and S2 correspond to Queensland Government's Ecosystem Health Monitoring Program monitoring Stns 906, 921, 510, 303 and 319 respectively) (Healthy Waterways 2014). For chl $a$ analysis, volumes between 0.5 and 11 of water were filtered on station through glass fibre carbon filters (GF/C, Whatman), and filters were stored frozen for subsequent extraction and spectrophotometric measurement. Chl a was analysed using a standard acetone extraction method (APHA 2005). Samples for DIN and SRP analysis were filtered through $0.45 \mu \mathrm{m}$ membrane filters and stored frozen. Samples were analysed for DIN (nitrate + nitrite and $\mathrm{NH}_{4}{ }^{+}$) and SRP using standard colorimetric methods (detection limit $0.14 \mu \mathrm{mol} \mathrm{l}^{-1}$ ) (APHA 2005).

\section{Measuring nutrient response: nitrogen enrichment bioassays}

Bioassays were used to assess nitrogen response of Moreton Bay phytoplankton, using $\mathrm{NH}_{4}{ }^{+}$as the substrate. $\mathrm{NH}_{4}{ }^{+}$may not be the most abundant form of nitrogen in coastal waters, but it was used in this study because it is the most energetically efficient form for phytoplankton to assimilate (Reynolds 2006, Bronk et al. 2007). Water samples for the bioassays were collected from 5 coastal stations at variable time intervals between August 2008 and April 2011 (stations were sampled 7 to 13 times during the study period; for full list of dates, see Table $\mathrm{S} 1$ in the Supplement at www.int-res.com/articles/suppl/m552 p081_supp.pdf). The stations were located in central and southern Moreton Bay (Fig. 1) and selected to capture the west to east gradient of nutrients associated with the river plume from the Brisbane and 
Logan Rivers. Sampling was carried out on the ebb tide approximately $2 \mathrm{~h}$ after high tide.

At each station on each sampling occasion, water samples were collected for nutrient enrichment bioassays and water quality data. For the nutrient enrichment bioassays, water was collected $15 \mathrm{~cm}$ below the surface into a $10 \mathrm{l}$ acid washed container. The $10 \mathrm{l}$ containers were then kept in cool shaded conditions and returned to the laboratory for processing within $5 \mathrm{~h}$. For water quality samples, surface water was collected into a bucket, and duplicate subsamples were taken for $\mathrm{chl} a$ and nutrient analyses and were processed in accordance with the methods described above. Surface salinity and temperature data were measured using a calibrated data logger (YSI-6920).

A modification of the method of Saeck et al. (2013a) was used for the nutrient enrichment bioassays. In total, 52 phytoplankton samples were collected for $\mathrm{NH}_{4}{ }^{+}$enrichment bioassays. For each sample, 15 to 18 clear plastic bottles were filled with $400 \mathrm{ml}$ of sample water (depending on number of treatments). Five to 6 treatments were used and typically had $0,0.3$, $0.6,3.0,6.0$ and $12.0 \mu \mathrm{mol} \mathrm{l} \mathrm{l}^{-1} \mathrm{NH}_{4}{ }^{+}$addition (final concentration) (5 treatments were sufficient to determine the 3 parameters in the asymptotic model described below; however, some preliminary experiments were conducted with 6 treatments before the model was fully formulated). There were 3 replicate bottles per treatment. Bioassays were incubated for $24 \mathrm{~h}$ under conditions of controlled light $-12 \mathrm{~h}$ total of dark and $12 \mathrm{~h}$ total of light at $180 \mu \mathrm{mol}$ (PAR) m ${ }^{-2}$ $\mathrm{s}^{-2}$ (commenced in light, at sunset switched to dark and $12 \mathrm{~h}$ later returned to light)—in a controlled-temperature room set to mimic ambient temperatures at the time of collection (ranging between 16 and $29^{\circ} \mathrm{C}$ depending on time of year). After $24 \mathrm{~h}$, the bioassays were dark-adapted for 20 min before 2 sub-samples were taken, and maximum quantum yield of PSII $\left(F_{\mathrm{v}} / F_{\mathrm{m}}\right)$ was measured using a PHYTO-PAM System II Emitter-Detector (PHYTO-ED) unit (Heinz Walz) with PHTYO-WIN software version 2.10.

The nutrient enrichment bioassay method described above was specifically designed to apply conditions under which $F_{\mathrm{v}} / F_{\mathrm{m}}$ would most closely reflect the maximum attainable value following enrichment. Relatively low light irradiance during incubation was used to prevent the interacting effect of photoinhibition on $F_{\mathrm{v}} / F_{\mathrm{m}}$ (Gordillo et al. 2001). Similarly, ambient temperatures were simulated during incubation to minimise physiological stress associated with temperature changes. Under nutrientreplete conditions, $F_{\mathrm{v}} / F_{\mathrm{m}}$ is reported to be largely independent of temperature (Geider et al. 1993) and irradiance (Kolber et al. 1988); as such, betweensample variation caused by different incubation temperatures was assumed to be minimal for the parameter of interest: $F_{\mathrm{v}} / F_{\mathrm{m}}$ response to nutrient enrichment. Trial experiments found no significant difference in the $F_{\mathrm{v}} / F_{\mathrm{m}}$ measured in natural marine samples after 24 and $48 \mathrm{~h}$ incubations (M. Burford pers. obs.). Previous research, using green microalgae cultures, indicated that $F_{\mathrm{v}} / F_{\mathrm{m}}$ is highest between 15 and $25 \mathrm{~h}$ following enrichment (Young \& Beardall 2003a,b). If, in contrast, nutrient supplies decline, such as may be the case in the control bioassay, $F_{\mathrm{v}} / F_{\mathrm{m}}$ can be maintained for at least $10 \mathrm{~h}$ because cells appear to have the capacity to reallocate nutrients to maintain PSII function (Young \& Beardall 2003a). Therefore, a $24 \mathrm{~h}$ incubation period had a relatively low risk of declines in $F_{\mathrm{v}} / F_{\mathrm{m}}$ caused by depletion of external nutrient pools. A period of dark adaptation prior to $F_{\mathrm{v}} / F_{\mathrm{m}}$ measures ensures that all reaction centres are open (Kolber et al. 1990). $F_{0}$ (minimum background fluorescence when all PSII reaction centres are open) and $F_{\mathrm{m}}$ (maximum fluorescence when all reaction centres are closed by a saturating pulse) are key parameters from which $F_{\mathrm{v}} / F_{\mathrm{m}}$ is derived (i.e. $F_{\mathrm{v}} / F_{\mathrm{m}}=\left(F_{\mathrm{m}}-F_{0}\right) F_{\mathrm{m}}^{-1}$ ) (Butler 1978, Maxwell \& Johnson 2000). These parameters stabilise at between 20 and 30 min of dark adaptation (Kolber et al. 1988, 1990, Geider et al. 1993), supporting the minimum period of 20 min dark adaptation used in this method.

\section{Calculating $\mathrm{N}_{95}$, an indicator of nitrogen response}

Preliminary $F_{\mathrm{v}} / F_{\mathrm{m}}$ data from nitrogen enrichment bioassays using natural phytoplankton samples showed an asymptotic-shaped response to increasing concentrations of nitrogen. Therefore, an asymptotic curve was used to model the nutrient enrichment bioassay data and calculate the value $\mathrm{N}_{95}$ (E. A. Saeck pers. obs.). $\mathrm{N}_{95}$ is an indicator of the amount of nitrogen required for the phytoplankton population to reach $95 \%$ of nitrogen-replete levels of photosynthetic efficiency (Fig. 2).

The following asymptotic function was used to calculate $\mathrm{N}_{95}$ models $F_{\mathrm{v}} / F_{\mathrm{m}}$ response as an increase from a minimum value $Y_{\min }$ the $F_{\mathrm{v}} / F_{\mathrm{m}}$ in the absence of any nitrogen stimulation, to $Y_{\max }$ the $F_{\mathrm{v}} / F_{\mathrm{m}}$ when photosynthetic processes are saturated by nitrogen:

$$
Y(\mathrm{~N})=Y_{\max }-\left(Y_{\max }-Y_{\min }\right) \mathrm{e}^{-\frac{3 \mathrm{~N}}{\mathrm{~N}_{95}}}
$$



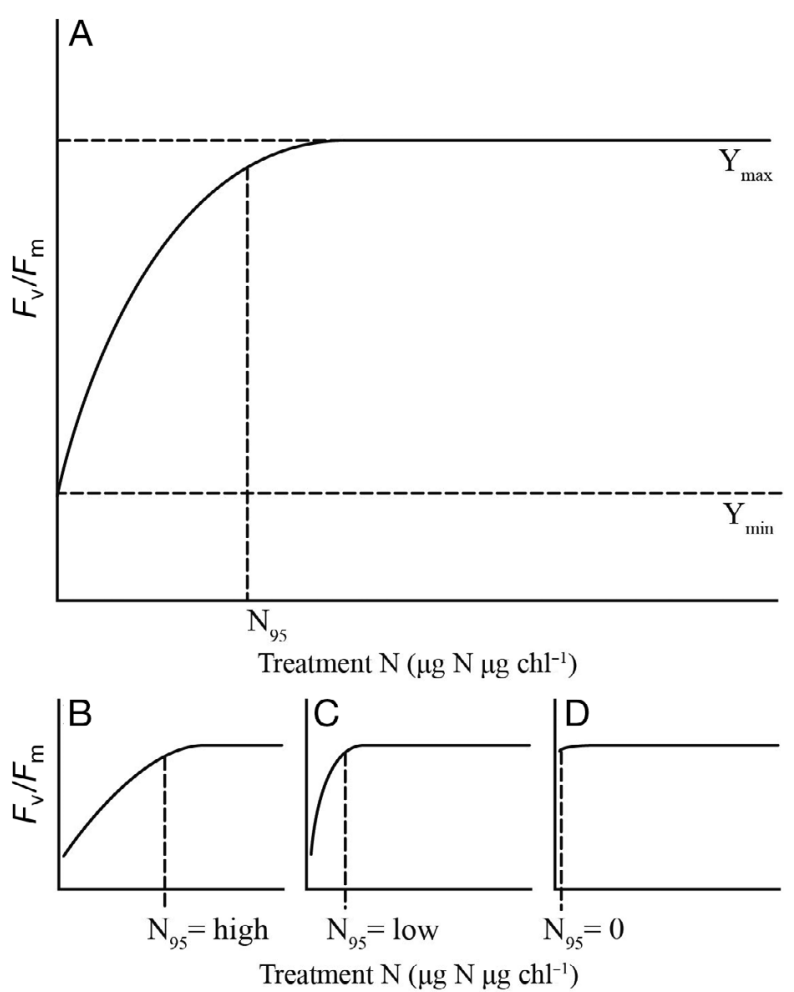

Fig. 2. (A) Conceptual representation of the asymptotic model used to calculate $\mathrm{N}_{95}$, which models $F_{\mathrm{v}} / F_{\mathrm{m}}$ response as an increase from a minimum value $Y_{\min }$ the $F_{\mathrm{v}} / F_{\mathrm{m}}$ in the absence of any nitrogen stimulation, to $Y_{\text {max }}$ the $F_{\mathrm{v}} / F_{\mathrm{m}}$ when photosynthetic processes are saturated by nitrogen. $\mathrm{N}_{95}$ is the concentration of nitrogen which must be added to samples to result in an increase in $F_{\mathrm{v}} / F_{\mathrm{m}}$ to $95 \%$ of the maximum possible $F_{\mathrm{v}} / F_{\mathrm{m}}$ increase, $Y_{\max }-Y_{\min }$ (or the specific nitrogen concentration required to reach $95 \%$ of saturation). The magnitude of $\mathrm{N}_{95}$ varies (B-D) as a function of the amount of treatment $\mathrm{N}(\mu \mathrm{g})$ required (per $\mu \mathrm{g}$ chl) to reach maximum $F_{\mathrm{v}} / F_{\mathrm{m}}$

where $Y(\mathrm{~N})$ is the $F_{\mathrm{v}} / F_{\mathrm{m}}$ of a sample phytoplankton population (following $24 \mathrm{~h}$ incubation) which has had a nutrient addition of $\mathrm{N}\left(\mu \mathrm{g} \mathrm{N} \mu \mathrm{ghl}^{-1}\right)$, and $\mathrm{N}_{95}$ is the concentration of nutrient addition (normalised to chl a) which corresponds to an increase in $F_{\mathrm{v}} / F_{\mathrm{m}}$ of $95 \%$ of the maximum possible $F_{\mathrm{v}} / F_{\mathrm{m}}$ increase, $Y_{\max }-$ $Y_{\min }$. A conceptual model of the asymptotic equation is presented in Fig. 2.

Nitrogen addition values were normalised to $\mathrm{chl} a$ concentrations in the statistical analysis to minimise the confounding effect of phytoplankton biomass on $\mathrm{N}_{95}$ values. This normalisation was necessary because the total nutrient demand of a natural phytoplankton sample over a $24 \mathrm{~h}$ period is the combined product of total biomass and the physiological nutrient status of the individual cells at the time of sampling (i.e. if a sample has relatively higher cell concentrations, relatively more nutrients must be added to reach maxi- mum photosynthetic efficiency). Normalising data to $\mathrm{chl}$ a prior to analysis and modelling ensures that the nutrient response curve used to calculate $\mathrm{N}_{95}$ represents the physiological nutrient status of the population at different levels of nutrient addition, irrespective of cell concentration. This standardisation allows $\mathrm{N}_{95}$ to be compared between samples.

Minimum and maximum $F_{\mathrm{v}} / F_{\mathrm{m}}\left(Y_{\min }, Y_{\max }\right), \mathrm{N}_{95}$ and associated $95 \%$ confidence intervals were determined for each sample by fitting Eq. (1) to the $F_{\mathrm{v}} / F_{\mathrm{m}}$ measured for the 5 to $6 \mathrm{NH}_{4}{ }^{+}$enrichment treatments using a non-linear least squares method in MATLAB2011a. The outputs were used to classify the sample phytoplankton communities as $\mathrm{N}$-responsive or not $\mathrm{N}$-responsive and to determine the $\mathrm{N}_{95}$ value to be used in the Moreton Bay spatial analysis. Cases were $N$-responsive if the $95 \%$ confidence intervals for $Y_{\max }$ and $Y_{\min }$ did not overlap, and the $95 \%$ confidence interval for $\mathrm{N}_{95}$ was larger than zero. All other cases were classified as not $\mathrm{N}$-responsive. For $\mathrm{N}$ responsive cases, the $\mathrm{N}_{95}$ was used as per the model calculation; in contrast, the not $N$-responsive cases were assigned an $\mathrm{N}_{95}$ value of zero (indicating that these cases were already within $95 \%$ of maximum $F_{\mathrm{v}} / F_{\mathrm{m}}$ at the time of sampling).

\section{Statistical analysis}

The performance of the asymptotic model for quantifying nutrient response was analysed by comparing the output with ANOVA tests. The purpose of this comparison was to identify cases where the asymptotic model had falsely identified cases as not $N$-responsive (which occurred when there was high within-treatment variability of $F_{\mathrm{v}} / F_{\mathrm{m}}$ values). Oneway ANOVA and Tukey HSD post-hoc tests identified cases that showed a significantly higher $F_{\mathrm{v}} / F_{\mathrm{m}}$ in $\geq 1$ of the treatment bioassays compared to the control bioassay, i.e. cases which were $N$-responsive. Where the asymptotic model falsely identified a case as not $N$-responsive (i.e. cases which were classified by the ANOVA as $N$-responsive), the cases were not included in the spatial analysis of Moreton Bay $\mathrm{N}_{95}$ values (see Table 1 for summary).

The phytoplankton $\mathrm{N}_{95}$ values were compared between stations by running Student's independent $t$ tests (with equal variance not assumed) and Levene's tests. The differences in the long-term $(5 \mathrm{yr})$ mean and variance of chl $a$ and nutrient concentrations between stations were tested by running paired-samples $t$-tests and Levene's tests. Statistical analyses were conducted using IBM SPSS Statistics v.19. 
Table 1. Summary of the classification criteria for nutrient response. $Y_{\min }$ is $F_{\mathrm{v}} / F_{\mathrm{m}}$ in the absence of any nutrient stimulation; $Y_{\max }$ is $F_{\mathrm{v}} / F_{\mathrm{m}}$ when saturated by that nutrient; and $\mathrm{N}_{95}$ is the concentration of nutrient addition (per $\mu \mathrm{g}$ chl) that corresponds to an increase in $F_{\mathrm{v}} / F_{\mathrm{m}}$ of $95 \%$ of the maximum possible $F_{\mathrm{v}} / F_{\mathrm{m}}$ increase, $Y_{\max }-Y_{\min }$

\begin{tabular}{|c|c|c|}
\hline Classification & Criteria & $\mathrm{N}_{95}$ \\
\hline Not N-responsive & $\begin{array}{l}\left|Y_{\max }\right|<\left|Y_{\min }\right| \text {, or } \mathrm{N}_{95} \text { is not significantly different from zero (i.e. lower } 95 \% \\
\text { confidence interval for } \mathrm{N}_{95} \text { is }<0 \text { ) }\end{array}$ & Assigned zero \\
\hline$N$-responsive & $\begin{array}{l}\left|Y_{\max }\right|>\left|Y_{\min }\right| \text { and } \mathrm{N}_{95} \text { is significantly different from zero (i.e. lower } 95 \% \\
\text { confidence interval for } \mathrm{N}_{95} \text { is }>0 \text { ) }\end{array}$ & Calculated from Eq. (2) \\
\hline $\begin{array}{l}\text { False negatives } \\
\text { (excluded from } \\
\text { spatial analysis) }\end{array}$ & $\begin{array}{l}\left|Y_{\max }\right|<\left|Y_{\min }\right| \text {, and/or } \mathrm{N}_{95} \text { is not significantly different from zero } \\
\text { (i.e. lower } 95 \% \text { confidence interval for } \mathrm{N}_{95} \text { is }<0 \text { ), but ANOVA } \\
\text { suggests significant difference between treatments }\end{array}$ & - \\
\hline
\end{tabular}

\section{RESULTS}

\section{$F_{\mathrm{v}} / F_{\mathrm{m}}$ values and asymptotic model output}

Maximum quantum yield of PSII $\left(F_{\mathrm{v}} / F_{\mathrm{m}}\right)$ values, as measured in the nutrient enrichment bioassays, were variable both spatially and temporally, ranging between 0.27 and 0.72 . The median $F_{\mathrm{v}} / F_{\mathrm{m}}$ for the $12 \mu \mathrm{mol} \mathrm{l}^{-1} \mathrm{~N}$ treatment at all stations was close to the maximum $F_{\mathrm{v}} / F_{\mathrm{mm}}$ value for nutrient replete cells (ranging from 0.61 to 0.64) (Geider et al. 1993, Kolber et al. 1994).

The asymptotic model for nitrogen response (Eq. 1) described the change in $F_{\mathrm{v}} / F_{\mathrm{m}}$ measured across the $\mathrm{NH}_{4}{ }^{+}$addition treatments, with 37 of 52 cases (i.e. $71 \%$ ) fitting with an $\mathrm{R}^{2}$ value higher than 0.70 (see Fig. S1 and Table S1 in the Supplement at www.int-res.com/articles/ suppl/m552p081_supp.pdf). Using parameters defined by the asymptotic model, 24 cases were classified as not $\mathrm{N}$-responsive, with 28 as $\mathrm{N}$-responsive. Using ANOVA post-hoc tests, 41 cases were $N$-responsive (i.e. the $F_{\mathrm{v}} / F_{\mathrm{m}}$ values of $\geq 1 \mathrm{NH}_{4}{ }^{+}$addition treatments were significantly higher than the control) $(\mathrm{p}<0.01)$, with the remaining 11 as not $N$-responsive (i.e. no significant difference in $F_{\mathrm{v}} / F_{\mathrm{m}}$ values between the control and $\mathrm{NH}_{4}{ }^{+}$addition treatment). The asymptotic model falsely identified 13 cases (i.e. $25 \%$ of all cases) as not $N$ responsive, and these 13 cases were not included in the Moreton Bay spatial analysis of $\mathrm{N}_{95}$, leaving 11 cases not $\mathrm{N}$ responsive and $28 \mathrm{~N}$-responsive cases for the spatial analysis. All cases classified by the ANOVA as not N-responsive were also classified by the asymptotic model as not $N$-responsive (i.e. there were no false positives).
The $\mathrm{N}_{95}$ value (i.e. the chl a normalised nitrogen addition required for phytoplankton photosynthetic efficiency to reach $95 \%$ of the maximum) was $0 \mu \mathrm{g} \mathrm{N}$ $\mu \mathrm{ghl}^{-1}$ for all cases classified as not $N$-responsive and ranged between 2.2 and $140.1 \mu \mathrm{g} \mathrm{N} \mu \mathrm{ghl}^{-1}$ for cases classified as $\mathrm{N}$-responsive (Fig. 3) (see also Table S1). Phytoplankton populations at the nearshore stations (C1 and S1) were more frequently not $N$-responsive compared to the offshore stations (C2, C3 and S2) (Fig. 4). Phytoplankton samples collected at the central bay nearshore station (C1) had significantly lower mean $\mathrm{N}_{95}$ values compared to the offshore stations $(\mathrm{C} 2$ and $\mathrm{C} 3 ; \mathrm{p}<0.05$ and $\mathrm{p}<0.001$, respectively) (C1: $8.4 \pm 5.8 \mu \mathrm{g} \mathrm{N} \mu \mathrm{ghl}^{-1}, \mathrm{n}=10 ; \mathrm{C} 2$ : $42.4 \pm 12.5 \mu \mathrm{g} \mathrm{N} \mu \mathrm{g} \mathrm{chl}^{-1}, \mathrm{n}=10 ; \mathrm{C} 3: 52.3 \pm 9.5 \mu \mathrm{g} \mathrm{N}$ $\mu \mathrm{g} \mathrm{chl}^{-1}, \mathrm{n}=9$ ). There was no significant difference in

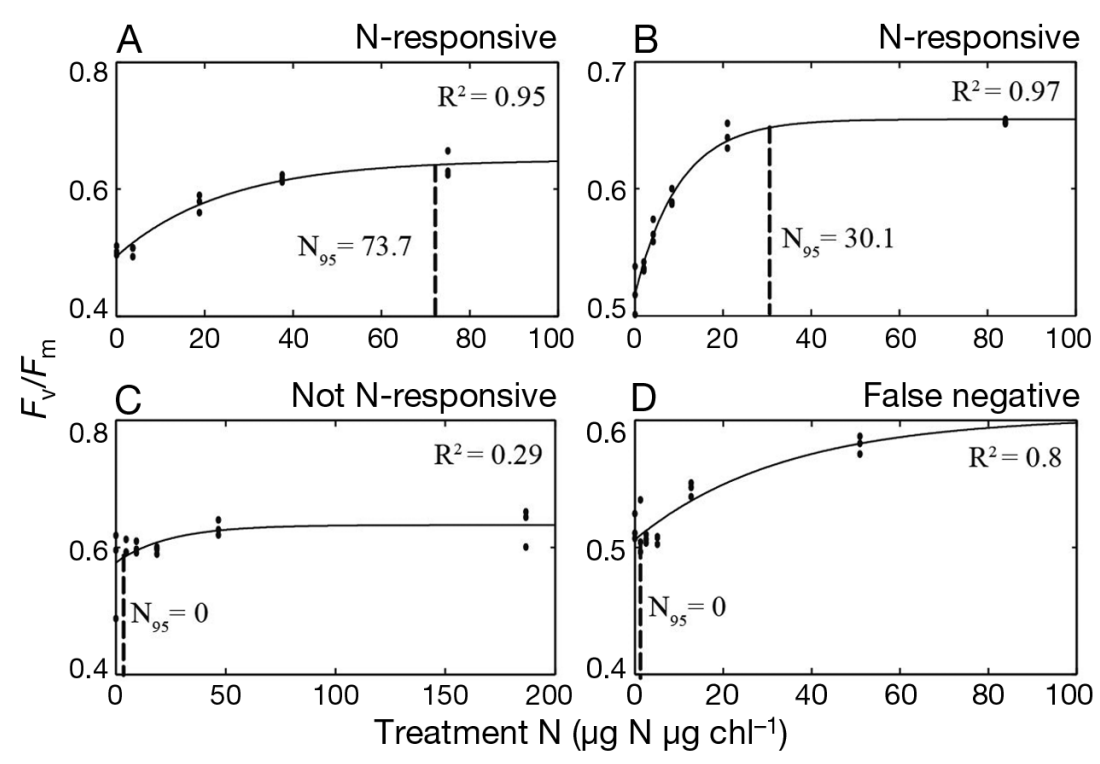

Fig. 3. Four examples of $F_{\mathrm{v}} / F_{\mathrm{m}}$ response curves and model results (see Fig. S1 in the Supplement at www.int-res.com/articles/suppl/m552p081_supp.pdf for all 52 cases). Plots show raw $F_{\mathrm{v}} / F_{\mathrm{m}}$ data (circles) from each bioassay and modelled data (line). The $\mathrm{R}^{2}$ and $\mathrm{N}_{95}$ values for each fitted curve are also shown. Example cases are (A) Stn C3, 30 Jan 2011; (B) Stn S1, 15 Nov 2009; (C) Stn C1, 4 Feb 2009; and (D) Stn C3, 13 Mar 2009 


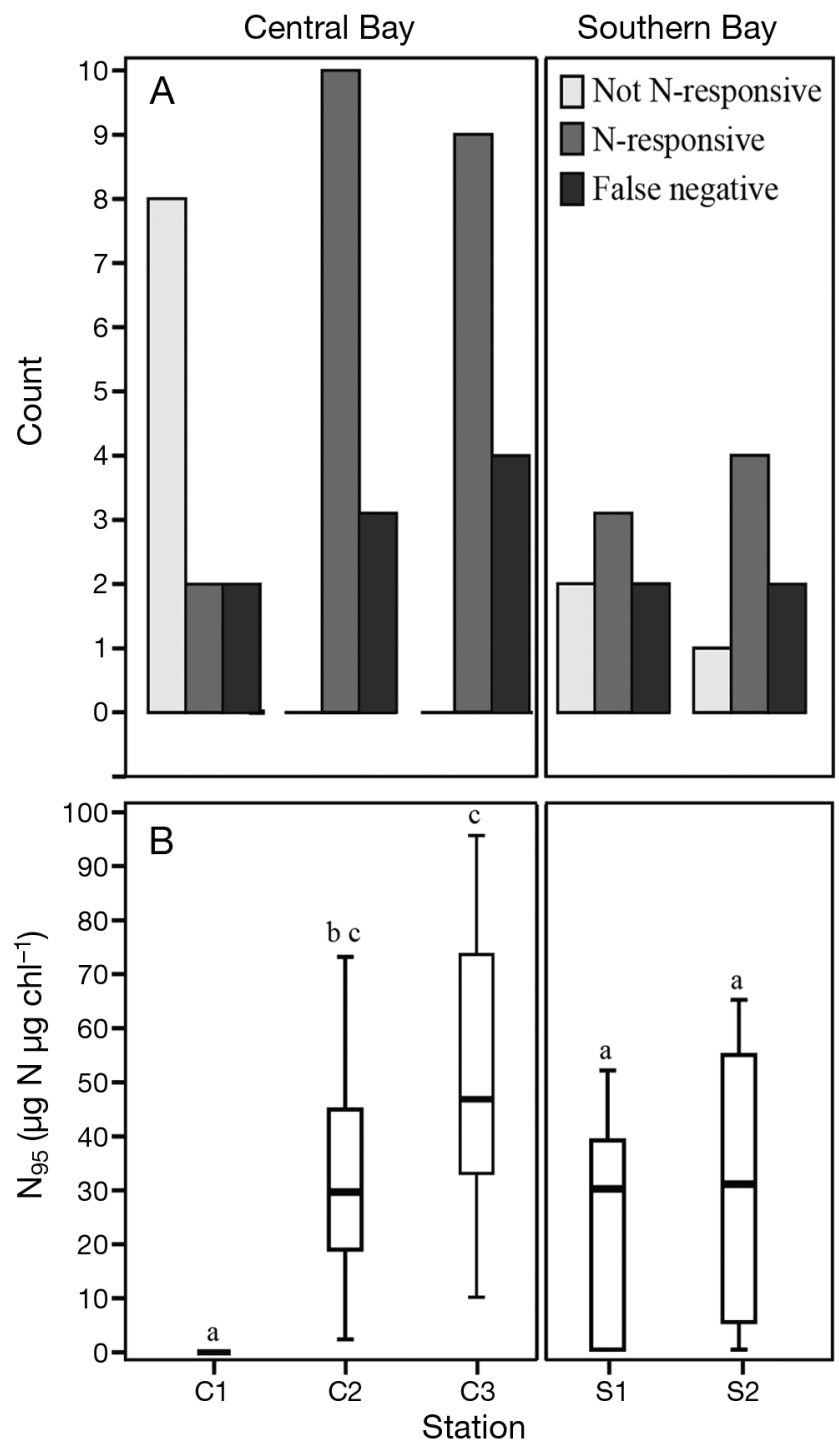

Fig. 4. The nutrient response at the 5 stations across central (C1, C2, C3) and southern Moreton Bay (S1, S2), showing (A) the number of phytoplankton samples classified as nutrient not $N$-responsive (light grey bars), $N$-responsive (medium grey bars), or False negative (dark grey bars); (B) box and whisker plot of $\mathrm{N}_{95}$ values with median, lower and upper quartiles and standard deviation. $t$-tests were used to compare each pair within each area of the bay, distributions with non-overlapping letter combinations are significantly different $(p<0.05)$

mean $\mathrm{N}_{95}$ values between stations in the Southern Bay (S1: $24.3 \pm 10.5 \mu \mathrm{g} \mathrm{N} \mu \mathrm{g} \mathrm{chl}{ }^{-1}, \mathrm{n}=5$; $\mathrm{S} 2: 31.4 \pm$ $13.0 \mu \mathrm{g} \mathrm{N} \mu \mathrm{g} \mathrm{chl} \mathrm{C}^{-1}, \mathrm{n}=5$ ).

\section{Water quality across the nutrient gradient}

Salinity, based on the $5 \mathrm{yr}$ of monitoring from January 2006 to December 2010 data (collected monthly), was significantly lower at the nearshore stations $(\mathrm{p}<$ 0.001) (Fig. 5). Chl a concentrations were significantly higher at the nearshore stations in the central bay $(\mathrm{p}<0.01)$; however, there was no significant difference between stations in the southern bay. Nutrient concentrations were significantly higher at nearshore stations compared to stations further offshore ( $p<0.001$ ), and variability was also higher (Levene's test, $p<0.01)$. There was one exception to this: the DIN level at the central station (C2) in the central bay was significantly lower than at the nearshore station (C1) $(p<0.001)$ but not significantly different from the offshore station (C3). The molar DIN:SRP ratios at all stations were below the Redfield (1958) ratio of $16: 1$, and there was no significant difference in ratio, or ratio variability, between the near and offshore stations in both central and southern bay.

\section{Phytoplankton nutrient response threshold}

The relationship between $\mathrm{N}_{95}$ and ambient nutrient conditions at the time of collection was analysed. There was no significant linear correlation between ambient DIN concentrations and phytoplankton nitrogen response, as indicated by the parameter $N_{95}$. Despite no correlation, there was evidence that when ambient DIN concentrations were higher than approximately $2 \mu \mathrm{mol} \mathrm{l}^{-1}$, then $\mathrm{N}_{95}$ were consistently low, with the majority of samples classified as not $\mathrm{N}$ responsive (9 of 11 cases, i.e. 82\%) (Fig. 6). In contrast, when ambient DIN concentrations were measured in situ at $<2 \mu$ mol $\mathrm{l}^{-1}$, then $\mathrm{N}_{95}$ values were highly variable (0 to $140 \mu \mathrm{g} \mathrm{N} \mathrm{\mu g} \mathrm{chl}{ }^{-1}$ ). The ambient DIN:SRP molar ratios, measured in situ at the time of bioassay sample collection, were consistently below Redfield of 16:1 (Fig. 7), with a significantly lower mean ratio for $N$-responsive cases $(2.54 \pm 2.03, \mathrm{n}=$ 28) compared to not $N$-responsive cases (5.83 \pm 2.77 , $\mathrm{n}=11)(\mathrm{p}<0.005)$.

\section{DISCUSSION}

This study proposes $\mathrm{N}_{95}$ as a new indicator for assessing the degree of nitrogen response in natural phytoplankton communities. $\mathrm{N}_{95}$ is calculated based on $F_{\mathrm{v}} / F_{\mathrm{m}}$, a measure of photosynthetic efficiency and a powerful indicator of nutrient stress, and as such, the approach advances options for the application of fluorescence-based measures to aquatic ecosystem assessment. $\mathrm{N}_{95}$ quantifies the chl a normalised nitrogen addition required for phytoplankton photo- 

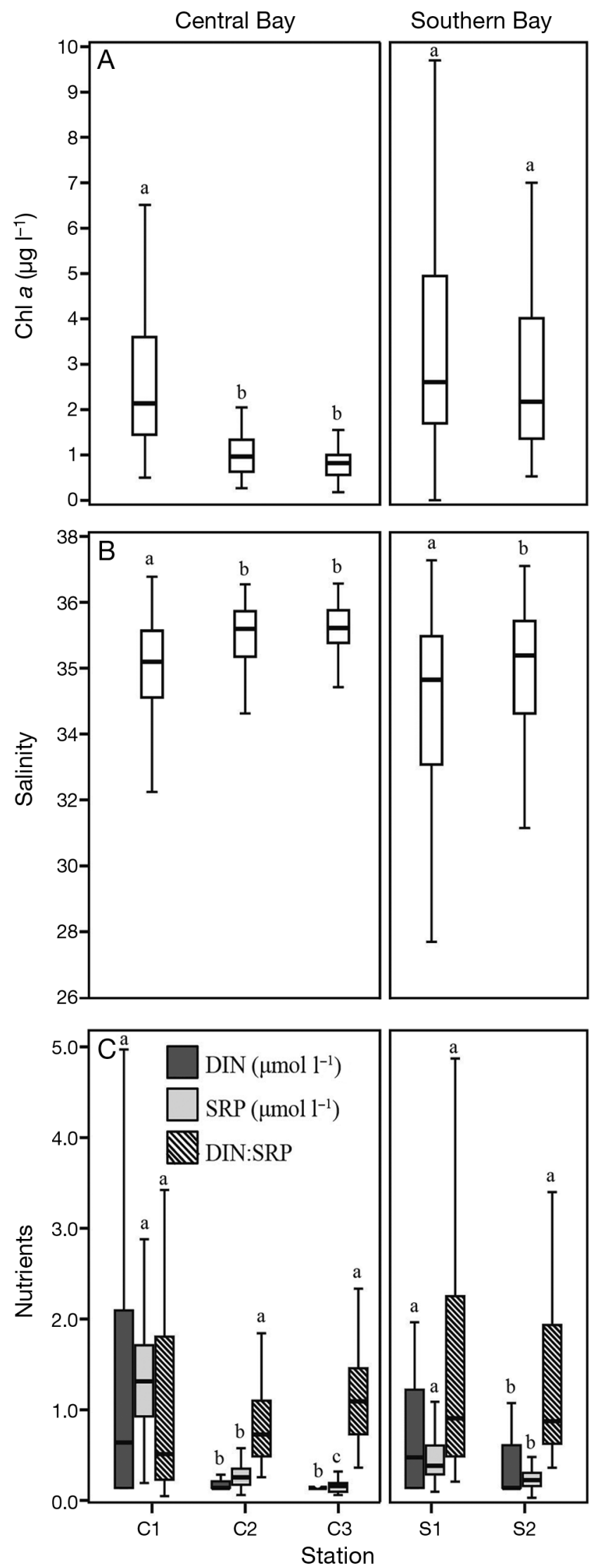

synthetic efficiency to reach $95 \%$ of the maximum within $24 \mathrm{~h}$. This measure indicates how close the community was to maximum response at the time of sampling. Natural phytoplankton communities with higher $\mathrm{N}_{95}$ values require the addition of more nitrogen per unit chl a to achieve a maximum response, indicating that the community is not nitrogen replete under the nitrogen conditions at the time of sampling. The value of quantifying short-term nutrient response with $\mathrm{N}_{95}$ is that $\mathrm{N}_{95}$ provides a continuous response variable that can be assessed against environmental drivers and used to characterise the spatial and temporal variability of nutrient response across a system.

$\mathrm{N}_{95}$ is a short-term physiological measure. It provides an indication of the relatively instantaneous nutrient response to a single nutrient (in this case, nitrogen) at the time of sampling. Importantly, it must be differentiated from classic measures of Liebig limitation because it does not seek to measure growth limitation (e.g. the nutrient load required to achieve maximum standing stock of algae) and does not consider other potentially limiting factors in the natural system (e.g. light, residence time and other nutrient forms). It is instead an assessment of instantaneous physiological status that can be used to characterise capacity to alleviate nutrient deficiency and potential to increase productivity (Geider et al. 1993, Beardall et al. 2001). This assessment can be used to provide greater understanding and predictability of algal biomass and potential for shifts in species composition in a system, which is of particular interest to management.

To validate the method and confirm $\mathrm{N}_{95}$ is a meaningful measure, the range of $\mathrm{N}_{95}$ values from this study (between approximately 2 and $140 \mu \mathrm{g} \mathrm{N} \mathrm{\mu g}$ $\mathrm{chl}^{-1}$ ) was compared with expected values derived from the literature. $\mathrm{N}_{95}$ represents the nitrogen addition needed (normalised to $\mathrm{chl}$ a) for the sampled phytoplankton population to reach $95 \%$ of nitrogenreplete photosynthetic efficiency following $24 \mathrm{~h}$ incubation. Logically, this concentration of $\mathrm{N}$ addition would fall within the range of potential $\mathrm{N}$ taken up

Fig. 5. Box and whisker plots of 5 yr of monitoring data (collected monthly from January 2006 to December 2010): (A) chl $a_{1}$ (B) salinity, (C) dissolved inorganic nitrogen (DIN), soluble reactive phosphorus (SRP), and DIN:SRP molar ratio across the bay, showing median, lower and upper quartiles and standard deviation, at central bay stations $\mathrm{C} 1(\mathrm{n}=58), \mathrm{C} 2$ $(\mathrm{n}=58)$ and $\mathrm{C} 3(\mathrm{n}=58)$ and southern bay stations $\mathrm{S} 1(\mathrm{n}=60)$ and S2 $(\mathrm{n}=60)$. $t$-tests were used to compare each pair within each area of the bay; distributions with non-overlapping letter combinations are significantly different $(p<0.01)$ 


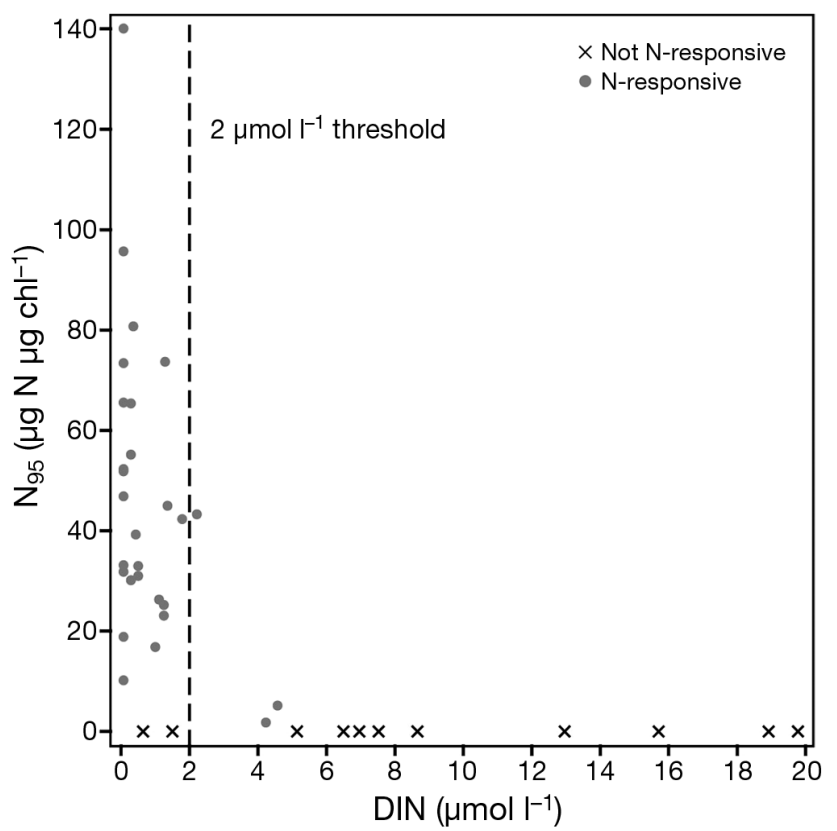

Fig. 6. Relationship between $\mathrm{N}_{95}$ and ambient dissolved

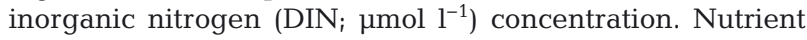
responses of phytoplankton samples are indicated either as not $N$-responsive $(\mathrm{n}=11$; black crosses) or $N$-responsive ( $\mathrm{n}=28$; grey circles). A black dashed line indicates where DIN is at $2 \mu \mathrm{mol} \mathrm{l}^{-1}$, the threshold above which phytoplankton response to nutrients (as measured by $\mathrm{N}_{95}$ ) was consistently low

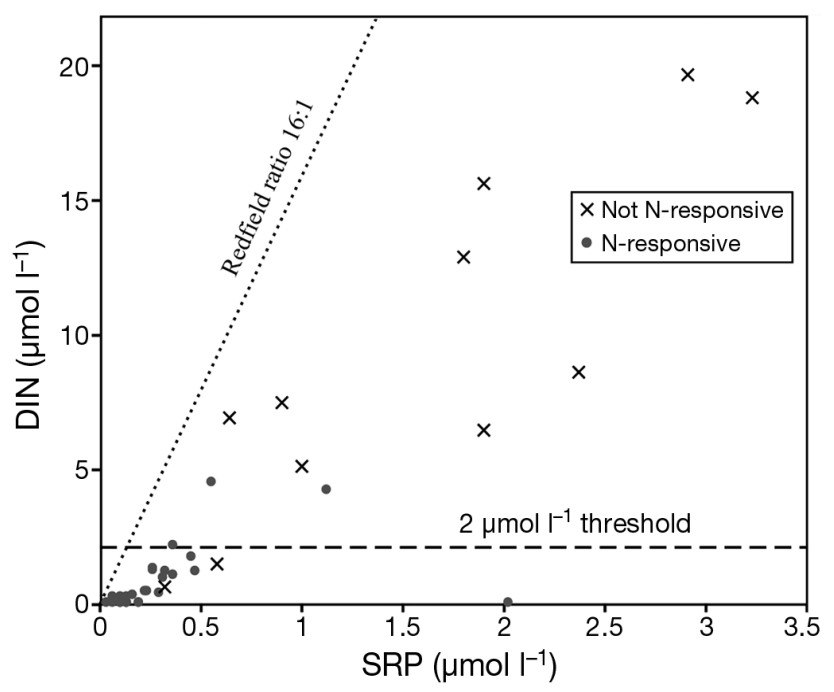

Fig. 7. Relationship between ambient soluble reactive phosphorus (SRP) and dissolved inorganic nitrogen (DIN; $\mu$ mol $\mathrm{l}^{-1}$ ) concentration. Nutrient responses of phytoplankton samples are indicated either as not $N$-responsive $(\mathrm{n}=11$; black crosses) or $N$-responsive ( $\mathrm{n}=28$; grey circles). The black dotted line indicates where DIN:SRP ratio is $16: 1$ (the Redfield ratio) and highlights that all samples in the study fell below this value. The black dashed line indicates where DIN is at $2 \mu \mathrm{mol} \mathrm{l}^{-1}$, the threshold above which phytoplankton response to nutrients (as measured by $\mathrm{N}_{95}$ ) was consistently low, despite a low DIN:SRP ratio over a $24 \mathrm{~h}$ period, which can be estimated using literature values of nitrogen uptake rates. For example, nitrogen uptake rates for central Moreton Bay, reported by Glibert et al. (2006), ranged from 19 to

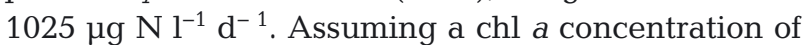
$1 \mu \mathrm{g} \mathrm{l}^{-1}$, the amount of total $\mathrm{N}$ taken up over a $24 \mathrm{~h}$ period would range from 19 to $1025 \mu \mathrm{g} \mathrm{N} \mu \mathrm{chl}^{-1}$. As such, the $\mathrm{N}_{95}$ values measured in this study fall within an expected range for Moreton Bay phytoplankton.

In this study, Moreton Bay phytoplankton frequently responded to nitrogen enrichment; however, the degree of nitrogen response, as indicated by $\mathrm{N}_{95}$, was spatially variable, reflecting the nutrient gradient present across the Bay. The gradient was characterised by a nearshore area with higher dissolved nutrient and chl a concentrations and an offshore zone of lower dissolved nutrient and chl a concentrations. The gradient is the result of freshwater inputs and associated nutrients from the Brisbane and Logan Rivers on the western side of the bay, which become diluted in the deeper waters on the eastern side of the bay (O'Donohue \& Dennison 1997, McEwan et al. 1998, Quigg et al. 2010). The nitrogen response of phytoplankton also changed with distance offshore, reflecting the gradient of declining river influence and DIN availability. In the nearshore zone, phytoplankton were more frequently not N-responsive, and $\mathrm{N}_{95}$ values were lower than the corresponding offshore stations. The scale of change in nutrient response with distance offshore was greater in the central bay where the gradient in DIN was stronger.

The pattern in nitrogen response ( $N$-responsive or not $N$-responsive) and degree of response $\left(\mathrm{N}_{95}\right)$ across a range of stations, seasons and other environmental factors can indicate when and where increased nutrient loadings have the potential to increase phytoplankton growth. In central Moreton Bay, nitrogen response changed with distance offshore, with the nearshore stations displaying the lowest nutrient response and $\mathrm{N}_{95}$ values. This pattern suggests that further nitrogen enrichment of the nearshore (within the bounds of Stn C1) would have little to no response. Instead, other conditions, such as light availability, are likely to be important for driving changes in phytoplankton growth and biomass within this zone. In contrast, if nitrogen enrichment affected areas further offshore (beyond Stn C2), a phytoplankton response would be likely.

Phytoplankton blooms are of particular ecological interest and management concern, so tools that assist in identifying regions where the phytoplankton community are physiologically closer to the maximum rate of response are valuable. Because $F_{\mathrm{v}} / F_{\mathrm{m}}$ reflects 
the potential to increase growth rate, productivity and bloom formation (Kolber et al. 1994, Behrenfeld et al. 1996), by extension, the continuous parameter $\mathrm{N}_{95}$ could be used as an indicator of bloom potential. $\mathrm{N}_{95}$ can thereby serve as the likelihood of rapid growth and phytoplankton biomass increase following nitrogen enrichment alone. A relatively high $\mathrm{N}_{95}$ value would indicate that the phytoplankton community has a relatively low potential to bloom under the current ambient nitrogen conditions. Indeed, bloom formation is the product of environmental constraints, such as nutrient supply rate, light availability, temperature, grazing rates and dilution rates; it is not solely a product of physiological nutrient status (Cloern 1996). If a system consistently has a low $\mathrm{N}_{95}$ and is defined as not $N$-responsive, this pattern likely indicates that light, temperature, loss processes and/or limitation by other nutrients (e.g. phosphorus) are constraining growth and accumulation. Conversely, if released from these constraining processes, biomass accumulation will likely occur. Future studies that test the relationship between $\mathrm{N}_{95}$ and phytoplankton growth over short time scales could further validate $\mathrm{N}_{95}$ as an indicator of bloom potential.

An analysis of the relationship between Moreton Bay $\mathrm{N}_{95}$ values and ambient nutrient conditions at the time of sampling was used to define a locally-specific threshold for phytoplankton community response to nutrient enrichment. By quantifying $\mathrm{N}_{95}$, this study found that the degree of nitrogen limitation of phytoplankton in Moreton Bay was highly variable when ambient nitrogen concentrations were low $\left(<2 \mu \mathrm{mol} \mathrm{l}^{-1}\right)$ (Fig. 6). However, at concentrations above approximately $2 \mu \mathrm{mol} \mathrm{l}^{-1}$ DIN, the phytoplankton response was consistently low (9 of 11 cases, i.e. $82 \%$ ). This level appears to be an ecologically important threshold for low nutrient response in the Moreton Bay phytoplankton community. Above $2 \mu \mathrm{mol} \mathrm{l}^{-1}$ DIN, the phytoplankton community consistently do not respond to further nitrogen enrichment, and as such, photosynthetic efficiency, growth and productivity are assumed to be mainly limited by other processes (e.g. light, phosphorus, iron or residence time). A similar ecological threshold has been identified in Chesapeake Bay, where Fisher et al. (2004) found phytoplankton communities were more likely to be $\mathrm{P}$ limited at $\mathrm{N}$ concentrations higher than $2 \mu \mathrm{mol} \mathrm{l}^{-1}$. These findings also contribute to persistent evidence that ambient dissolved nutrient conditions cannot necessarily be used to indicate nutrient limitation, especially at low concentrations (Tamminen \& Andersen 2007, Trommer et al. 2013).

Predicting eutrophication trajectories for aquatic ecosystems under pressure from elevating nutrient loads is challenging (Duarte et al. 2009, Carstensen et al. 2011). Furthermore, the response to nutrient reduction management strategies is not simply a reversal of the original eutrophication trajectory, with systems often not returning to the same state observed prior to eutrophication (Cloern et al. 2007, Conley et al. 2009, Duarte et al. 2009). Chl a and nutrients are the most widely applied indicators of eutrophication due to the relative ease of sampling. However, an independent measure of chl a concentration lacks information about physiological state or degree of nutrient stress. Similarly, the concentration of nutrient pools and nutrient ratios do not reflect likely response of the phytoplankton community to changes in nutrient availability (Syrett 1981, Hecky \& Kilham 1988, Riebesell \& Wolf-Gladrow 2002), as the findings of this study also highlight. Moreton Bay DIN:SRP ratios were consistently measured at below the Redfield value of 16:1 (Redfield 1958), suggesting the system was nitrogen limited; however, phytoplankton response to nitrogen enrichment was highly variable, and in some cases, the phytoplankton showed little to no response (even at low DIN concentrations) (Figs. $6 \&$ 7). Therefore, new tools, such as the one outlined in this study, can provide an understanding of the current nutrient status of phytoplankton, potential response to increased nutrient availability, and thresholds above which significant changes may occur (Beardall et al. 2001).

Major advantages to using $\mathrm{N}_{95}$ as a nutrient-response indicator, compared to alternate approaches for measuring short-term physiological response, are that the incubations are relatively simple to set up, the incubation period is relatively short $(24 \mathrm{~h})$, the $F_{\mathrm{v}} / F_{\mathrm{m}}$ measurements are simple to make, and expensive reagents and a knowledge of ambient nutrient conditions are not required. Growth experiments, in contrast, require longer incubation periods (several days to weeks) and use biomass as the endpoint, resulting in a relatively unrealistic reflection of short-term nutrient response as conditions within the bioassays increasingly deviate from the natural state (e.g. Hayes et al. 1984, Piehler et al. 2004). The shorter the incubation period, the less likely other nutrients become limiting, and the less the community composition deviates from the original community sampled (Carpenter 1996, Downing et al. 1999). As such, the technique to derive $\mathrm{N}_{95}$ using $F_{\mathrm{v}} / F_{\mathrm{m}}$ measured following relatively short incubations $(24 \mathrm{~h})$ minimises the inherent issues with incubating assays for extended periods under artificial conditions.

$\mathrm{N}_{95}$ provides an alternative indicator of growth in mixed-natural phytoplankton populations where there 
is limited time and resources. A suite of traditional methods and equations already exist for measuring and calculating phytoplankton response to nutrient enrichment (e.g. Eppley \& Thomas 1969, Brzezinski et al. 2008); however, all are only indicators of the final response in terms of biomass, and few relate as closely to physiological conditions for growth as $\mathrm{N}_{95}$. In contrast, $\mathrm{N}_{95}$ is an indicator calculated from measures of photosynthetic processes and therefore is more closely related to growth conditions than many other traditional tools. Ultimately, the specific indicator selected to analyse eutrophication and likely nutrient response depends on context; however, short-term physiological measures such as $\mathrm{N}^{95}$ can provide more insight than standard measures of chl $a$, nutrients, nutrient ratios, uptake rates and growth rates.

This is the first time this method has been applied, and further refinements are inevitably needed. The method may need fine-tuning in other environments where phytoplankton responses to nutrients require longer bioassay incubation times (e.g. the maximum $F_{\mathrm{v}} / F_{\mathrm{m}}$ levels may be reached by $24 \mathrm{~h}, 48 \mathrm{~h}$ or another time period). Additionally, the method needs an initial calibration to ensure that nitrogen enrichment levels used in enrichment bioassays are appropriate to optimise the phytoplankton response in the system of study. The method was more likely to underestimate response to $\mathrm{N}$ in general: none of the samples identified as not $N$-responsive by the ANOVA were falsely classified by the asymptotic model, but $25 \%$ of the samples that responded to $\mathrm{N}$ according to the ANOVA did not have a significant $\mathrm{N}_{95}$.

In summary, the approach developed in this study is a tool for quantifying physiological phytoplankton nutrient response in natural phytoplankton communities. This new indicator, $\mathrm{N}_{95}$, is a continuous variable that can be used to assess the spatial and temporal variability of nutrient response across a water body. Areas with a relatively lower sensitivity to nutrient enrichment or potential for phytoplankton blooms and symptoms of eutrophication can be identified. Furthermore, combining the output measures - nutrient response and $\mathrm{N}_{95}$ - with information about ambient nutrient conditions can be used to identify ecologically significant nutrient enrichment thresholds. The advantage of measuring $\mathrm{N}_{95}$, over other short-term physiological measures, is that it is relatively fast and simple to carry-out, making it a better candidate for monitoring programs.

Acknowledgements. The authors thank the Queensland Department of Environment and Resource Management, Healthy Waterways, P. Filet and D. Rissik for sharing the long-term water quality data used in this analysis. The authors also thank P. Ralph and M. Baird for providing feedback on initial ideas for the approach and model used to calculate $\mathrm{N}_{95}$, and 2 anonymous reviewers for their detailed comments that significantly improved our manuscript. Access to boating resources provided by the Queensland Government and the University of Queensland is thankfully acknowledged, as is the field and laboratory assistance from J. Gruythuysen, S. Pausina, P. Hough, M. Whittle, S. Faggotter, D. Valdez, B. Woodward, M. Prentice, C. Polsen, A. Steward and many others. Funding and support for the project was provided by the Australian Government through an Australian Research Council Linkage Project grant, Healthy Waterways and the Australian Rivers Institute.

\section{LITERATURE CITED}

Abal E, Moore KB, Gibbes BR, Dennison W (eds) (2002) State of South-East Queensland Waterways Report 2001. Moreton Bay Waterways and Catchments Partnership, Brisbane

APHA (American Public Health Association) (2005) Standard methods for the examination of water and wastewater, 21st edn. APHA, Washington DC

Australian Bureau of Statistics (2012) 3218.0-Regional population growth, Australia, 2010-11. Commonwealth of Australia, Canberra. www.abs.gov.au

$>$ Beardall J, Young E, Roberts S (2001) Approaches for determining phytoplankton nutrient limitation. Aquat Sci 63:44-69

Behrenfeld MJ, Bale AJ, Kolber ZS, Aiken J, Falkowski PG (1996) Confirmation of iron limitation of phytoplankton photosynthesis in the equatorial Pacific Ocean. Nature 383:508-511

Bronk DA, See JH, Bradley P, Killberg L (2007) DON as a source of bioavailable nitrogen for phytoplankton. Biogeosciences 4:283-296

Brzezinski MA, Dumousseaud C, Krause JW, Measures CI, Nelson DM (2008) Iron and silicic acid concentrations together regulate $\mathrm{Si}$ uptake in the equatorial Pacific Ocean. Limnol Oceanogr 53:875-889

Burford MA, Revill AT, Palmer DW, Clementson L, Robson BJ, Webster IT (2011) River regulation alters drivers of primary productivity along a tropical river-estuary system. Mar Freshw Res 62:141-151

Butler WL (1978) Energy distribution in the photochemical apparatus of photosynthesis. Annu Rev Plant Physiol 29: 345-378

> Carpenter SR (1996) Microcosm experiments have limited relevance for community and ecosystem ecology. Ecology 77:677-680

> Carstensen J, Sánchez-Camacho M, Duarte CM, KrauseJensen D, Marbà N (2011) Connecting the dots: responses of coastal ecosystems to changing nutrient concentrations. Environ Sci Technol 45:9122-9132

> Cloern JE (1996) Phytoplankton bloom dynamics in coastal ecosystems: a review with some general lessons from sustained investigation of San Francisco Bay, California. Rev Geophys 34:127-168

> Cloern JE, Jassby AD, Thompson JK, Hieb KA (2007) A cold phase of the East Pacific triggers new phytoplankton blooms in San Francisco Bay. Proc Natl Acad Sci USA 104:18561-18565

Conley DJ, Paerl HW, Howarth RW, Boesch DF and others (2009) Controlling eutrophication: nitrogen and phosphorus. Science 323:1014-1015

Dennison W, Abal E (1999) Moreton Bay study: a scientific basis for the Healthy Waterways Campaign. South East Queensland Regional Water Quality Management 
Strategy, Brisbane

Downing JA, Osenberg CW, Sarnelle O (1999) Meta-analysis of marine nutrient-enrichments: variation in the magnitude of nutrient limitation. Ecology 80:1157-1167

> Duarte CM, Conley DJ, Carstensen J, Sánchez-Camacho M (2009) Return to neverland: shifting baselines affect eutrophication restoration targets. Estuaries Coasts 32:29-36

Eppley RW, Thomas WH (1969) Comparison of half-saturation constants for growth and nitrate update of marine phytoplankton. J Phycol 5:375-379

Eyre B, McKee LJ (1999) Task nutrient budgets (NB) phase 2 final report. South East Queensland Regional Water Quality Strategy, Brisbane

> Eyre B, Hossain S, McKee LJ (1998) A suspended sediment budget for the modified sub-tropical Brisbane River estuary, Australia. Estuar Coast Shelf Sci 47:513-522

Fisher TR, Gustafson AB, Perry E, Haas LW, Karrh R, Jasinksi D (2004) A resource limitation model of phytoplankton growth: derivation and validation, report to Maryland Department of Natural Resources. University of Maryland, Cambridge, MD

> Geider RJ, Greene RM, Kolber Z, Macintyre HL, Falkowski PG (1993) Fluorescence assessment of the maximum quantum efficiency of photosynthesis in the western North Atlantic. Deep-Sea Res I 40:1205-1224

Glibert PM, Heil CA, O'Neil JM, Dennison WC, O'Donohue MJH (2006) Nitrogen, phosphorus, silica, and carbon in Moreton Bay, Queensland, Australia: differential limitation of phytoplankton biomass and production. Estuaries Coasts 29:209-221

Gordillo FJL, Jiménez C, Chavarría J, Xavier Niell F (2001) Photosynthetic acclimation to photon irradiance and its relation to chlorophyll fluorescence and carbon assimilation in the halotolerant green alga Dunaliella viridis. Photosynth Res 68:225-235

> Hayes PK, Whitaker TM, Fogg GE (1984) The distribution and nutrient status of phytoplankton in the Southern Ocean between $20^{\circ}$ and $70^{\circ} \mathrm{W}$. Polar Biol 3:153-165

Healthy Waterways (2014) Ecosystem health monitoring program. Available at www.healthywaterways.org/Eco systemHealthMonitoringProgram/Home.aspx (accessed 23 Feb 2014)

> Hecky RE, Kilham P (1988) Nutrient limitation of phytoplankton in freshwater and marine environments-a review of recent evidence on the effects of enrichment. Limnol Oceanogr 33:796-822

Kolber Z, Zehr J, Falkowski P (1988) Effects of growth irradiance and nitrogen limitation on photosynthetic energy conversion in photosystem II. Plant Physiol 88:923-929

Kolber Z, Wyman KD, Falkowski PG (1990) Natural variability in photosynthetic energy conversion efficiency: a field study in the Gulf of Maine. Limnol Oceanogr 35:72-79

Kolber ZS, Barber RT, Coale KH, Fitzwateri SE and others (1994) Iron limitation of phytoplankton photosynthesis in the equatorial Pacific Ocean. Nature 371:145-149

Kruskopf M, Flynn KJ (2006) Chlorophyll content and fluorescence responses cannot be used to gauge reliably phytoplankton biomass, nutrient status or growth rate. New Phytol 169:525-536

Lippemeier S, Hintze R, Vanselow KH, Hartig P, Colijn F (2001) In-line recording of PAM fluorescence of phytoplankton cultures as a new tool for studying effects of fluctuating nutrient supply on photosynthesis. Eur J Phycol 36:89-100

- Maxwell K, Johnson GN (2000) Chlorophyll fluorescencea practical guide. J Exp Bot 51:659-668

McCauley EK, Tomlinson RB (2006) The evolution of Jumpinpin. Institution of Engineers Australia, Brisbane
McEwan J, Gabric AJ, Bell PRF (1998) Water quality and phytoplankton dynamics in Moreton Bay, south-eastern Queensland. II. Mathematical modelling. Mar Freshw Res 49:227-239

O'Donohue MJH, Dennison WC (1997) Phytoplankton productivity response to nutrient concentrations, light availability and temperature along an Australian estuarine gradient. Estuaries 20:521-533

O'Donohue MJ, Glibert PM, Dennison WC (2000) Utilization of nitrogen and carbon by phytoplankton in Moreton Bay, Australia. Mar Freshw Res 51:703-712

Parkhill J, Maillet G, Cullen J (2001) Fluorescence-based maximal quantum yield for PSII as a diagnostic of nutrient stress. J Phycol 37:517-529

Piehler MF, Twomey LJ, Hall NS, Paerl HW (2004) Impacts of inorganic nutrient enrichment on phytoplankton community structure and function in Pamlico Sound, NC, USA. Estuar Coast Shelf Sci 61:197-209

Quigg A, Litherland S, Phillips JA, Kevekordes K (2010) Phytoplankton productivity across Moreton Bay, Australia: the impact of water quality, light and nutrients on spatial patterns. In: Davie PJF, Phillips JA (eds) Proceedings of the thirteenth international marine biological workshop, the marine fauna and flora of Moreton Bay, Queensland. Mem Queensl Mus Nature 54:355-372

Redfield AC (1958) The biological control of chemical factors in the environment. Am Sci 46:205-221

Reynolds CS (2006) Ecology of phytoplankton. Cambridge University Press, Cambridge

Riebesell U, Wolf-Gladrow DA (2002) Supply and uptake of inorganic nutrients. In: Williams PJ, Thomas DN, Reynolds CS (eds) Phytoplankton productivity: carbon assimilation in marine and freshwater ecosystems. Blackwell Science, Oxford, p 109-140

Saeck EA, Hadwen WL, Rissik D, O'Brien KR, Burford MA (2013a) Flow events drive patterns of phytoplankton distribution along a river-estuary-bay continuum. Mar Freshw Res 64:655-670

Saeck EA, O'Brien KR, Weber TR, Burford MA (2013b) Changes to chronic nitrogen loading from sewage discharges modify standing stocks of coastal phytoplankton. Mar Pollut Bull 71:159-167

Skinner JL, Gillam E, Rohlin CJ (1998) The demographic future of the Moreton region. In: Tibbetts I, Hall N, Dennison W (eds) Moreton Bay and catchment. University of Queensland, Brisbane, p 67-78

Syrett PJ (1981) Nitrogen metabolism of microalgae. Can Bull Fish Aquat Sci 210:182-210

- Tamminen T, Andersen T (2007) Seasonal phytoplankton nutrient limitation patterns as revealed by bioassays over Baltic Sea gradients of salinity and eutrophication. Mar Ecol Prog Ser 340:121-138

Trommer G, Leynaert A, Klein C, Naegelen A, Beker B (2013) Phytoplankton phosphorus limitation in a North Atlantic coastal ecosystem not predicted by nutrient load. J Plankton Res 35:1207-1219

Wood MD, Oliver RL (1995) Fluorescence transients in response to nutrient enrichment of nitrogen-and phosphorus-limited Microcystis aeruginosa cultures and natural phytoplankton populations: a measure of nutrient limitation. Funct Plant Biol 22:331-340

Young EB, Beardall J (2003a) Photosynthetic function in Dunaliella tertiolecta (Chlorophyta) during a nitrogen starvation and recovery cycle. J Phycol 39:897-905

Young EB, Beardall J (2003b) Rapid ammonium- and nitrate-induced perturbations to chl a fluorescence in nitrogen-stressed Dunaliella tertiolecta (Chlorophyta). J Phycol 39:332-342 